Research Article

\title{
Prevalence of morbidity and morbidity pattern among primary school children in rural area of Jalna, Maharashtra, India
}

\author{
Hina Kausar*, Rajesh C Sambutwad, Mohd Shafee
}

\begin{abstract}
Department of Community Medicine, Indian Institute of Medical Science and Research, Warudi, Badnapur,
\end{abstract} Maharashtra, India

Received: 21 April 2016

Accepted: 16 May 2016

*Correspondence:

Dr. Hina Kausar,

E-mail: drhina84@gmail.com

Copyright: ( ) the author(s), publisher and licensee Medip Academy. This is an open-access article distributed under the terms of the Creative Commons Attribution Non-Commercial License, which permits unrestricted non-commercial use, distribution, and reproduction in any medium, provided the original work is properly cited.

\section{ABSTRACT}

Background: Children are nation's greatest asset. School children constitute around $25 \%$ of total population of India. They are more vulnerable to infections and malnutrition than rest of the population. The objective of the study was to find the prevalence of morbidity among school children and assessment of the morbidity pattern among school children.

Methods: The present cross sectional study was carried out from January 2015 to march 2015 in randomly selected primary schools of rural area of Jalna, Maharashtra. The study subjects were school going children, total number of 352 children studying from grade $\mathrm{I}$ to $\mathrm{V}$ who were present on the day of examination were included the study. The children were examined for the presence of different morbidities.

Results: Total three hundred and fifty two children were included in the present study. Total $60 \%$ of school children were found to have one or other morbidity. Prevalence of morbidities among girls was more than boys. The prevalence of nutritional deficiency diseases was the most common $52.27 \%$ followed by respiratory infections $15.34 \%$ and then infective and parasitic diseases $12.78 \%$. Ear discharge was present in $7 \%$ of children more in boys than girls but it was not statistically significant. The prevalence of dental caries was $6.66 \%$ in boys and $5.34 \%$ in girls. Lymphadenopathy was present in $4.2 \%$ of children.

Conclusions: Prevalence of morbidities found to be 1.89 morbidities per sick child and 1.13 morbidities per child. The prevalence of nutritional deficiency diseases was the most common followed by respiratory infections and then infective and parasitic diseases. Prevalence of eye, ear and skin problems were low in this study. Most of the diseases among school going children were preventable.

Keywords: Morbidity, School children, Morbidity pattern, Rural area

\section{INTRODUCTION}

Children are nation's greatest asset. School children constitutes around $25 \%$ of total population of India. ${ }^{1}$ They are more vulnerable to infections and malnutrition than rest of the population. ${ }^{2}$ Health of the child is viewed as absence of disease and not as comprehensive health in developing countries. ${ }^{3}$ Children are the country's biggest human investment for development. ${ }^{4}$ School a convergence center for health and education is a setting that plays an important role in physical, social, mental and emotional development of children. ${ }^{5}$ Beginning of school health services in our country dates back to 1909 , when for the first time medical examination of school children was carried out. ${ }^{6}$ The WHO expert committee on school health services noted as long as 1950 that ' to learn effectively children need good health'. 7 After the family schools are the most important places of learning for children. A survey among the school children in India revealed that about half of the ailments found are related to unsanitary condition and lack of personal hygiene. ${ }^{8}$ health problems of school children vary from 
one place to another. Surveys carried out indicate that the main emphasis will fall in malnutrition, infectious diseases, intestinal parasites, diseases of the skin, eye and ear and dental problems. ${ }^{3}$ Childhood is the best time for children to learn health seeking behavior. Education that provides basic academic skill, specific knowledge, attitude and skill related to their physical , psychological and social well-being. ${ }^{9}$ According to modern concepts, school health service is an economical and powerful means of raising community health and more important in future generations. By simply doing periodic medical examination and daily morning inspection of students, we can detect many more problems and treat accordingly. ${ }^{10}$ The present study was conducted as part of the school health services to assess the common existing health problems of school children and to arouse health consciousness among the children.

The objective of the study was to; (1) to find the prevalence of morbidity among school children; and (2) to assess the morbidity pattern among school children.

\section{METHODS}

The study was started after ethical clearance and study was approved by institutional ethical committee in Indian institute of medical science and research, Warudi, Badnapur, Maharashtra, India.

The present cross sectional study was carried out in the rural area of Badnapur taluqa of Jalna district, Maharashtra, from January 2015 to March 2015. The study subjects were school going children. There were seventy primary school present in Badnapur taluqa ; one school from village name Shekta and two school from
Warudi village were selected by simple random sampling. Prior permission was taken from the principal of the school after explaining the aims and objectives of the study. From these selected schools, a total number of 352 children studying from grade I to IV, who were present on the day of examination were included the study.

The children were examined for the presence of different morbidities by ophthalmologist followed by dentist and a pediatrician and basic information of the child was taken from class teacher. General examination included head to toe examination than systemic examination was done. Visual acuity was assessed using snellen's chart. The information was collected on pre designed and pretested proforma.

The collected data entered in Excel sheet and analyzed using appropriate statistical test.

\section{RESULTS}

Total three hundred and fifty two children were included in the present study out of which one hundred and sixty five were boys and one hundred and eighty seven were girls. The mean age was $8.36 \pm 1.73$. Maximum number of children was in the age group of 9-10 years (Table 1).

Total $60 \%$ of school children were found to have one or other morbidity. Total 352 children were suffering from 399 morbidity, 1.89 morbidities per sick child and 1.13 morbidities per child. Prevalence of morbidities among girls was more than boys in this study but it was not found to be statistically significant. $\left(X^{2}=1.14\right.$; d.f $=1$, $\mathrm{P}>0.05$ ) (Table 2).

Table1: Distribution of children according to age and gender.

\begin{tabular}{|llllll|}
\hline Age (years) & \multicolumn{2}{c}{ Boys } & \multicolumn{2}{c}{ Girls } & Total (percentage) \\
& Number & Percentage & Number & Percentage & $73(20.74)$ \\
\hline $5-6$ & 33 & 20 & 40 & 21.4 & $112(31.82)$ \\
\hline $7-8$ & 61 & 36.96 & 51 & 27.3 & $133(37.78)$ \\
\hline $9-10$ & 54 & 32.7 & 79 & 42.3 & $34(9.66)$ \\
\hline $11-12$ & 17 & 10.3 & 17 & 9.09 & $352(100)$ \\
\hline Total & 165 & 100 & 187 & 100 & \\
\hline
\end{tabular}

Table 2: Distribution of children according to morbidity.

\begin{tabular}{|llllll|}
\hline \multirow{2}{*}{ Morbidity } & \multicolumn{2}{c}{ Boys } & \multicolumn{2}{c|}{ Girls } & Total (percentage) \\
\cline { 2 - 6 } & Number & Percentage & Number & Percentage & $211(60)$ \\
\hline Present & 94 & 56.96 & 117 & 62.6 & $141(40)$ \\
\hline Absent & 71 & 43.04 & 70 & 37.4 & $352(100)$ \\
\hline Total & 165 & 100 & 187 & 100 & \\
\hline
\end{tabular}

$\left(\mathrm{X}^{2}=1.14 ; \mathrm{d} . \mathrm{f}=1 ; \mathrm{P}>0.05\right)$.

The prevalence of nutritional deficiency diseases was the most common $52.27 \%$ followed by respiratory infections $15.34 \%$ and then infective and parasitic diseases $12.78 \%$.
Nutritional deficiency diseases and respiratory infections were slightly more in girls $54.54 \%$ and $15.5 \%$ than boys $49.69 \%$ and $15.15 \%$. Infective and parasitic diseases was 
more in boys $16.96 \%$ than girls $9.09 \%$. The prevalence of ear, eye and diseases of oral cavity was $12.12 \%, 8.48 \%$ and $8.48 \%$ respectively among boys while the corresponding figure among their female counterpart was found to be $7.48 \%, 9.62 \%$ and $8 \%$ respectively. Diseases of the digestive system was slightly more in girls $4.27 \%$ than boys $3 \%$. Prevalence of skin disease among boys and girls revealed to be almost equal (Table 3 ).

Table3: Distribution of children according to prevalence of morbidities.

\begin{tabular}{|c|c|c|c|c|c|c|}
\hline \multirow{2}{*}{ ICD code } & \multirow{2}{*}{ Diseases } & \multicolumn{2}{|l|}{ Boys } & \multicolumn{2}{|c|}{ Girls } & \multirow{2}{*}{$\begin{array}{l}\text { Total } \\
\text { (Percentage) }\end{array}$} \\
\hline & & Number & Percentage & Number & Percentage & \\
\hline A00-B99 & Infective and parasitic & 28 & 16.96 & 17 & 9.09 & $45(12.78)$ \\
\hline E50-E64 & Nutritional deficiency & 82 & 49.69 & 102 & 54.54 & $184(52.27)$ \\
\hline H00-H59 & Eye diseases & 14 & 8.48 & 18 & 9.62 & $32(9.09)$ \\
\hline H60-H95 & Ear diseases & 20 & 12.12 & 14 & 7.48 & $34(9.65)$ \\
\hline J00-J99 & Respiratory diseases & 25 & 15.15 & 29 & 15.5 & $54(15.34)$ \\
\hline K00-K14 & Diseases of oral cavity & 14 & 8.48 & 15 & 8.02 & $29(8.23)$ \\
\hline L00-L99 & Skin diseases & 4 & 2.42 & 4 & 2.13 & $8(2.27)$ \\
\hline R10- R19 & Diseases of digestive system & 5 & 3.03 & 8 & 4.27 & $13(3.69)$ \\
\hline
\end{tabular}

Table 4: Distribution of children according to type of morbidities.

\begin{tabular}{|c|c|c|c|c|c|c|}
\hline \multirow{2}{*}{ Disease } & \multicolumn{2}{|c|}{ Boys } & \multicolumn{2}{|c|}{ Girls } & \multirow{2}{*}{$\begin{array}{c}\text { Total } \\
\text { (Percentage) }\end{array}$} & \multirow{2}{*}{$\begin{array}{l}\text { Test of } \\
\text { significance }\end{array}$} \\
\hline & No. & $\%$ & No. & $\%$ & & \\
\hline $\begin{array}{l}\text { Anemia (clinically) } \\
\text { Present } \\
\text { Absent }\end{array}$ & $\begin{array}{l}28 \\
137\end{array}$ & $\begin{array}{l}16.96 \\
83.04\end{array}$ & $\begin{array}{l}52 \\
135\end{array}$ & $\begin{array}{l}27.8 \\
72.2\end{array}$ & $\begin{array}{l}80(22.72) \\
272(77.27)\end{array}$ & $\begin{array}{l}X^{2}=5.86 ; \text { d.f }=1 \\
P-0.007\end{array}$ \\
\hline $\begin{array}{l}\text { Lips } \\
\text { Angular stomatitis } \\
\text { Normal }\end{array}$ & $\begin{array}{l}3 \\
162 \\
\end{array}$ & $\begin{array}{l}1.81 \\
98.18\end{array}$ & $\begin{array}{l}2 \\
185\end{array}$ & $\begin{array}{l}1.06 \\
98.93\end{array}$ & $\begin{array}{l}5(1.4) \\
347(98.57)\end{array}$ & $\begin{array}{l}X^{2}=0.35 ; d . f=1 \\
P-0.5\end{array}$ \\
\hline $\begin{array}{l}\text { Dental caries } \\
\text { Present } \\
\text { Absent }\end{array}$ & $\begin{array}{l}11 \\
154 \\
\end{array}$ & $\begin{array}{l}6.66 \\
93.33 \\
\end{array}$ & $\begin{array}{l}10 \\
177 \\
\end{array}$ & $\begin{array}{l}5.34 \\
94.65\end{array}$ & $\begin{array}{l}21(5.96) \\
331(94.03)\end{array}$ & $\begin{array}{l}X^{2}=0.27 ; d . f=2 \\
P-0.6\end{array}$ \\
\hline $\begin{array}{l}\text { Skin diseases } \\
\text { Scabies } \\
\text { Others } \\
\text { Normal }\end{array}$ & $\begin{array}{l}2 \\
2 \\
161\end{array}$ & $\begin{array}{l}0.56 \\
0.56 \\
9.69\end{array}$ & $\begin{array}{l}3 \\
1 \\
183 \\
\end{array}$ & $\begin{array}{l}1.6 \\
0.53 \\
97.72 \\
\end{array}$ & $\begin{array}{l}5(1.4) \\
3(0.85) \\
344(97.72) \\
\end{array}$ & $\begin{array}{l}X^{2}=0.56 ; d . f=2 \\
P-0.7\end{array}$ \\
\hline $\begin{array}{l}\text { Ear discharge } \\
\text { Present } \\
\text { Absent }\end{array}$ & $\begin{array}{l}15 \\
150\end{array}$ & $\begin{array}{l}9.09 \\
90.9\end{array}$ & $\begin{array}{l}10 \\
177\end{array}$ & $\begin{array}{l}5.34 \\
94.65 \\
\end{array}$ & $\begin{array}{l}25(7.1) \\
327(92.89)\end{array}$ & $\begin{array}{l}X^{2}=1.86 ; \text { d.f }=1 \\
P-0.08\end{array}$ \\
\hline $\begin{array}{l}\text { URTI } \\
\text { Present } \\
\text { Absent }\end{array}$ & $\begin{array}{l}24 \\
141 \\
\end{array}$ & $\begin{array}{l}14.54 \\
85.45\end{array}$ & $\begin{array}{l}27 \\
160\end{array}$ & $\begin{array}{l}14.43 \\
85.56\end{array}$ & $\begin{array}{l}54(15.34) \\
298(84.65)\end{array}$ & $\begin{array}{l}X^{2}=0.008 ; d . f=1 \\
P-0.4\end{array}$ \\
\hline $\begin{array}{l}\text { Diseases of eye } \\
\text { Refractive error } \\
\text { Conjunctivitis } \\
\text { Normal }\end{array}$ & $\begin{array}{l}13 \\
1\end{array}$ & $\begin{array}{l}7.87 \\
0.6\end{array}$ & $\begin{array}{l}15 \\
3\end{array}$ & $\begin{array}{l}8.02 \\
1.6\end{array}$ & $\begin{array}{l}28(7.95) \\
4(1.13)\end{array}$ & $\begin{array}{l}X^{2}=0.76 ; \text { d.f }=2 \\
P-0.6\end{array}$ \\
\hline $\begin{array}{l}\text { Lymphadenopathy } \\
\text { Present } \\
\text { Absent }\end{array}$ & $\begin{array}{l}9 \\
156 \\
\end{array}$ & $\begin{array}{l}5.45 \\
94.54\end{array}$ & $\begin{array}{l}6 \\
181 \\
\end{array}$ & $\begin{array}{l}3.2 \\
95.73\end{array}$ & $\begin{array}{l}15(4.2) \\
337(95.73)\end{array}$ & $\begin{array}{l}X^{2}=0.066 ; d . f=1 \\
P-0.3\end{array}$ \\
\hline $\begin{array}{l}\text { Hepatomegaly } \\
\text { Present } \\
\text { Absent } \\
\end{array}$ & $\begin{array}{l}1 \\
164 \\
\end{array}$ & $\begin{array}{l}0.6 \\
99.39\end{array}$ & $\begin{array}{l}2 \\
185 \\
\end{array}$ & $\begin{array}{l}1.06 \\
98.93\end{array}$ & $\begin{array}{l}3(0.85) \\
349(99.1)\end{array}$ & $\begin{array}{l}X^{2}=0.011 ; \mathrm{d} . \mathrm{f}=1 \\
\mathrm{P}-0.4\end{array}$ \\
\hline $\begin{array}{l}\text { Splenomegaly } \\
\text { Present } \\
\text { Absent }\end{array}$ & $\begin{array}{l}1 \\
164\end{array}$ & $\begin{array}{l}0.6 \\
99.39\end{array}$ & $\begin{array}{l}1 \\
186 \\
\end{array}$ & $\begin{array}{l}0.53 \\
99.46\end{array}$ & $\begin{array}{l}02(0.56) \\
350(99.43)\end{array}$ & $\begin{array}{l}X^{2}=0.38 ; \text { d.f }=1 \\
P-0.2\end{array}$ \\
\hline
\end{tabular}


Among the different types of morbidities nutritional anemia was most common $22.72 \%$, followed by URTI $15.4 \%$.the prevalence of anemia was more in girls $27.8 \%$ than boys $16.96 \%$ it was statistically significant $\left(\mathrm{X}^{2}=5.86, \mathrm{~d} . \mathrm{f}=1, \mathrm{P}-0.007\right)$, URTI was almost similar in boys and girls. Among eye diseases refractive error was common $7.95 \%$ and prevalence of conjunctivitis was $1.13 \%$. Ear discharge was present in $7 \%$ of children more in boys than girls but it was not statistically significant $\left(\mathrm{X}^{2}=1.86 ; \mathrm{d} . \mathrm{f}=1 ; \mathrm{P}-0.08\right)$. The prevalence of dental caries was $6.66 \%$ in boys and $5.34 \%$ in girls. Lymphadenopathy was present in $4.2 \%$ of children. Total $1.4 \%$ of children had angular stomatitis. Hepatomegaly and splenomegaly was present in less than $1 \%$ of children each (Table 4).

\section{DISCUSSION}

In this study the prevalence of total morbidity was $60 \%$. This prevalence was less than in a study by Kaushik et al who found $85.3 \%$, Sharma et al who found $77.9 \%$ and saluja et al found $67.8 \%$ total morbidity, and more than study by Rani et al who found $41.52 \%$ and Shinde et al found $54.83 \%$ total morbidity in their study. ${ }^{4,11-14}$ Nutritional deficiency diseases were most common in present study $52.27 \%$ and $22.72 \%$ children were anemic clinically. Anemia was more in girls than boys and it was statistically significant. A study by Kaushik et al found $56.9 \%$ children had nutritional deficiencies, Shinde et al found $15.69 \%$ children had anemia and Kulkarni et al found $15.8 \%$ children were anemic and $8.18 \%$ in a study by Nigudgi et al. ${ }^{3,5,11,14}$ In a study by Harish Chandra et al found $33.9 \%$ anemia prevalence and Rani et al found $26.9 \%$, these anemia prevalence were more than this study. ${ }^{2,4}$ Following nutritional deficiencies respiratory infections was common with $15.34 \%$ prevalence, this prevalence was less compared to $42.78 \%$ in a study by JP Singh et al while Kulkarni et al, Sayed et al and Shinde et al found $14.3 \%, 12.11 \%$ and $3.77 \%$ prevalence of URTI respectively. ${ }^{5,8,10,14}$ Total $12.7 \%$ of children had worm infestation, this was more than findings of Sharma et al, Shinde et al ${ }^{14}$ and JP Singh ${ }^{10}$ et al who found $5.27 \%$, $4.94 \%$ and $2.5 \%$ respectively. ${ }^{10,12,14}$ The present study found $7.95 \%$ refractive error, this prevalence was less than $10.12 \%$ in a study by Deshpande et al and $10.41 \%$ in a study by Kulkarni et al. ${ }^{5,15}$ Total $1.13 \%$ of children had conjunctivitis in this study, Kaushik et al found $4 \%$ and Deshpande et al found it $2.57 \%$ which was more than this study. ${ }^{11.15}$ Ear discharge was present in $7.1 \%$ of children that was more than $2.6 \%$ in a study by Sayed et al and Sharma et al found $5.59 \%$ of children had ear problems. ${ }^{8,12}$ In this study $5.96 \%$ of children had dental caries, less prevalence compared to $31.86 \%$ in study by Kulkarni et al, $24.86 \%$ in study by Sharma et al and $22.8 \%$ in study by Saluja et al. ${ }^{5,12,13}$ The prevalence of angular stomatitis was low in this study compared to $27.5 \%$ in a study by Kaushik et al. ${ }^{11}$ The present study found $4.2 \%$ children had lymphadenopathy, this was slightly lower than findings of Sharma et al who found it $5 \% .^{12}$ In this study the prevalence of skin infections was
$1.4 \%$, low compared to $11.4 \%$ in study by Kaushik et al and $6.53 \%$ in study by Sharma et al. ${ }^{11,12}$ In this study less than $1 \%$ of children had hepatomegaly and splenomegaly each, Kaushik et el found $2.9 \%$ children had hepatomegaly and $1.1 \%$ children had splenomegaly. ${ }^{11}$

\section{CONCLUSION}

In this study the health status of school children was not satisfactory, more so in girls than boys. Prevalence of morbidities found to be 1.89 morbidities per sick child and 1.13 morbidities per child. The prevalence of nutritional deficiency diseases was the most common followed by respiratory infections and then infective and parasitic diseases. Prevalence of eye, ear, skin problems were low compared to other studies. Most of the diseases among school going children were preventable.

\section{Recommendations}

Prevention, early recognition and prompt treatment of diseases by regular screening of students would definitely reduce morbidity so that they can attain their full potential in the course of their education.

\section{ACKNOWLEDGEMENTS}

Authors are grateful to the school authorities, teachers and the students who have co-operated for the study. The inspiration and help provided by the Dean of Institute, ophthalmology department, faculty of dentistry and pediatric department are also duly acknowledged.

\section{Funding: No funding sources Conflict of interest: None declared}

Ethical approval: The study was approved by the Institutional Ethics Committee

\section{REFERENCES}

1. Lal S, Adarsh, Pankaj. Reproductive \& Child Health, Policies \& Programmes in India. Text Book of Community Medicine. 3rd Edition, Page-144.

2. Tiwari HC, Gahlot A, Mishra R. Health profile of primary school children: study from a rural health block of Kanpur. Journal of Evolution of medical and dental Sciences. 2013;2(3):6941-5.

3. Nigudi SR, Reddy S, Kaptey R. Morbidity pattern of school children of Gulberga City. Media Innovatica. 2012;1(2):20-4.

4. Rani V, Kumar D, Singh NP, Jain PK, Kumar S, Singh NP, Dixit AM. Morbidity pattern among primary school children in a rural area of Uttar Pradesh. National Journal of Community medicine. 2104;5(4):392-6.

5. Kulkarni MM, Rathi P, Eshwari K, Ashok K, Kamath VG. Health status of school children in rural area of coastal Karnataka. Medical Journal of Dr. DY Patil University. 2016;9(1):31-5. 
6. Park K. Preventive Medicine in Obstetrics, Pediatrics and Geriatrics. Text Book of Preventive and Social Medicine, 23nd edn. Jabalpur: Banarsidas Bhanot, 2009. pp.578.

7. WHO Expert Committee on School health services .Report on the first session. Geneva, World Helath Organization, 1950. (WHO Technical report series, No30)

8. Sayed S, Gangam S, Sayed S, Rao R. Morbidity pattern and its associated factors among school children of an urban slum in Hyderabad, India. International Journal of medical Science and Public Health. 2013;4(9):1277-81.

9. UNICEF/IRC. A Manual on School Sanitation and Hygiene; 1998. Washington, DC: International Water and Sanitation Center, 2001. pp. 1-2.

10. Singh JP, Kariwal P, Gupta SB, Singh AK, Imtiaz D. Nutritional status and morbidity among school going children. A scenario from a rural India. Sch J App Med Sci. 2014;2(1):379-83.

11. Kaushik A, Bansal A, Jain PK, Kumar S, Yadav RK, Singh SP. Morbidity pattern and their sociodemographic co-relates among rural primary school children in eastern Uttar Pradesh: A cross sectional study. Indian Journal of Community Health. 2014;26(1):30-6.

12. Sharma U, Sharma JP, Sharma A. Morbidity pattern among school going children in rural area of Dehradhun. International Journal of Scientific study. 2015;3(1):179-82.

13. Saluja N, Garg S, Chopra H. Prevalence of morbidity and morbidity pattern in school children(5-11yrs) in urban area of Meerut. The International Journal of Epidemiology. 2010;9(2)

14. Shinde M, Joshi A, Trivedi A. Morbidity pattern among school children of rural area of Obaidullaganj block of Raisen district of madhiya Pradesh. International Journal of Advances in Medicine. 2015;2(2):144-6.

15. Jayant DD, Malathi K. Prevalence of ocular morbidities among school children in rural area of North Maharashtra in India. National Journal of Community Medicine. 2011;2(2):249-54.

Cite this article as: Kausar H, Sambutwad RC, Shafee M. Prevalence of morbidity and morbidity pattern among primary school children in rural area of Jalna,

Maharashtra, India. Int J Community Med Public Health 2016;3:1623-7. 